\title{
Pengembangan Media Pembelajaran Berbasis Multimedia Pada Mata Pelajaran Informatika Kelas VII Di SMP Negeri 1 Seririt
}

\author{
Si Luh Made Intan Pebriyanti ${ }^{1}$, Dewa Gede Hendra Divayana ${ }^{2}$, I Made Windu Antara Kesiman ${ }^{3}$ \\ Program Studi Pendidikan Teknik Informatika \\ Universitas Pendidikan Ganesha \\ Singaraja, Indonesia \\ Email: luh.made.intan@undiksha.ac.id ${ }^{1}$, hendra.divayana@undiksha.ac.id ${ }^{2}$, $\underline{\text { antara.kesiman@undiksha.ac.id }}^{3}$
}

\begin{abstract}
Abstrak-Mata pelajaran Informatika saat ini masih terbilang baru jadi peserta didik merasa sulit dalam mengolah mata pelajaran ini dan terlihat monoton apalagi pada jenjang pendidikan sebelum nya (Sekolah Dasar) mereka belum pernah mendapat mata pelajaran Informatika jadi mata pelajaran ini masih sangat awam. Padahal di era sekarang ini pemanfaatan komputer dalam bidang pendidikan sangat penting karena sekarang kita berada di era industri 4.0 yang memanfaatkan teknologi yang seharusnya mata pelajaran Informatika di pelajari sejak dini. Maka dari itu peneliti berkeinginan membantu siswa SMPN 1 Seririt membuatkan media pembelajaran interaktif berbasis multimedia agar bisa lebih mudah mempelajari dan dapat memotivasi siswa belajar Informatika khususnya materi Berpikir Komputasional. Selain itu fasilitas di SMPN 1 Seririt juga sangat memadai dan mendukung dalam pelajaran Informatika ini. Konsep pada media pembelajaran ini tidak berfokus dengan materi saja jadi peneliti menambahkan audio, video visual, animasi dan quis yang akan di coba oleh siswa nantinya. Peneliti menggunakan bantuan Software Articulate Storyline 3 untuk pembuatan media ini. Metode perancangan penelitian ini menggunakan Multimedia Development Life Cycle (MDLC) yang terdiri dari 6 tahapan, yaitu Concept, Design, Material collecting, Assembly, Testing, dan Distribution. Beberapa pengujian dilakukan untuk mengetahui tingkat kefektifan media pembelajaran berkonsep multimedia, yang diantaranya ialah uji Ahli isi dengan hasil presensate 100\%, uji ahli media diperoleh $100 \%$.
\end{abstract}

Kata Kunci : Media pembelajaran Interaktif,Informatika,Berpikir Komputasional,MDLC

\section{PENDAHULUAN}

Mata pelajaran Informatika merupakan mata pelajaran yang bangkit kembali di pelajari di tingkat SMP. Sebelumnya kita ketahui mata pelajaran Informatika ini terkenal dengan sebutan mata pelajaran TIK (Teknologi Informasi dan Komunikasi). Dibanding mata pelajaran TIK yang terdahulu, sepintas mata pelajaran Informatika ini memberi ruang dan target lebih besar untuk proses pembelajaran Informatika di sekolah.
Secara nyata tertulis di Permendikbud No. 36/ 2018, ada pasal perubahan yakni Pasal 10A: Pelaksanaan pembelajaran Informatika sebagai mata pelajaran pilihan dilaksanakan mulai tahun ajaran 2019/ 2020 sesuai kesiapan sekolah. Mengembalikan TIK menjadi mata pelajaran merupakan bagian dari langkah strategis Kemendikbud dalam menghadapi tantangan revolusi industri 4.0. Mata pelajaran Informatika menjadi ilmu yang wajib dikuasi para pelajar di pendidikan dasar dan menengah. konsep mata pelajaran Informatika berbeda dengan pendidikan TIK meskipun ada beberapa hal yang diadaptasi. Mata pelajaran Informatika tidak hanya mempelajari beragam perangkat lunak komputer, tetapi juga memecahkan masalah dan berpikir kritis. Peserta didik dituntut berpikir komputasional dengan mempelajari beragam disiplin ilmu.

Kabupaten Buleleng hanya ada beberapa sekolah menengah pertama yang mempelajari Informatika, salah satunya adalah SMP Negeri 1 Seririt. Dalam mempelajari Informatika peserta didik diharapkan mampu menguasai keterampilan operasi dasar komputer yaitu mengaktifkan komputer, mematikan komputer, sistem operasi pengelolaan kata dan angka. Tujuan pembelajaran yang diinginkan tersebut dapat dicapai dengan pendekatan tertentu. Berdasarkan observasi lapangan yang peneliti lakukan di SMP Negeri 1 Seririt, Guru pengampu mata pelajaran Informatika memberikan silabus mata pelajaran Informatika, silabus ini sudah dirancang serta mempertimbangkan kebutuhan masa depan. Sepintas, Kompetensi Dasar yang dimunculkan adalah kompetensi yang sangat menantang dan tidak mudah. Buktinya ada KD Berpikir Komputasional. Ini adalah indikator materi yang lumayan berat. Artinya, untuk menguasai mata pelajaran Informatika dengan baik, diperlukan Sarana yang mendukung, buku pelajaran yang memadai serta guru yang kompeten. Peserta didik tidak diajari sekedar MS Word, Excel atau Power Point harus lebih dari itu. Karena pada 
mata pelajaran Informatika sekarang membahas tentang materi Perangkat keras komputer, Sistem operasi dan berbagai perangkat lunak, Bekerja dengan data, Mengenal dan menggunakan pemrograman visual, Kolaborasi dalam masyarakat digital terakhir Mengenal dan menerapkan konsep berfikir komputasional.

Hasil observasi peneliti di SMP Negeri 1 Seririt terdapat lab komputer, artinya sekolah ini siap dengan sarana pendukung selain buku paket pelajaran Informatika. Tenaga pengajar mata pelajaran Informatika di SMPN 1 Seirit ini hanya ada 1 orang dan jadwal mengajar guru sudah terlalu padat sehingga guru tidak cukup waktu untuk membuat media pembelajaran yang kreatif, inovatif, dan efektif untuk meningkatkan motivasi belajar peserta didik yang cenderung mempunyai motivasi belajar sedang dalam belajar Informatika, serta tidak membuat peserta didik merasa bosan dan susah dalam menerima pelajaran yang diberikan.

Ketersediaan media menjadi penting karena guru bukanlah satu-satunya sumber belajar sekaligus media penyampai. Dalam mengatasi masalah tersebut diperlukan penelitian berkaitan pengembangan media pembelajaran interaktif. Salah satu upaya yang memadai untuk itu adalah dengan merancang dan membuat sebuah media pembelajaran interaktif berbasis multimedia. Keberhasilan media direncanakan dan dirancang dengan baik agar mampu menambah penguasaan keterampilan peserta didik. Dengan menggunakan media pembelajaran interaktif diharapkan mampu menambah wawasan peserta didik dan sasaran pembelajaran dapat ditingkatkan. Peneliti berniat merancang media pembelajaran dengan menggunakan program Articulate Storyline 3. Media pembelajaran interaktif yang dihasilkan memuat isi berupa gambar, audio, video, dan teks serta adanya soal evaluasi untuk lebih memahami materi yang disampaikan. Dengan adanya media ini diharapkan peserta didik mampu memahami materi dengan baik dan efektif, karena pembelajaran yang efektif yaitu peserta didik harus melihat, mendengar, merasakan, dan mengalami.

Pemanfaatan lingkungan sekolah atau sarana sekolah sebagai tambahan sumber belajar, dengan pola di dalam maupun di luar kelas (Lab Komputer) dapat dimanfaatkan untuk mengoptimalkan kegiatan pembelajaran. Siswa cenderung lebih semangat jika belajar informatika langsung diperaktekan dengan komputer,maka dari itu media interaktif ini harus menjadi komponen efektif agar dapat mendukung pembelajaran efektif yang nantinya menjadi sumber belajar siswa.
Perancangan dan pembuatan media pembelajaran interaktif ini sangat penting untuk dilaksanakan karena sebelumnya belum pernah dilaksanakannya, dapat membantu dan mempermudah peserta didik kelas VII SMP Negeri 1 Seririt dalam mempelajari dan memahami keterampilan berfikir komputasional serta penelitian ini bisa dijadikan suatu rekomendasi untuk materi yang disampaikan dalam pelatihan pengembangan diri peserta didik untuk belajar mandiri. Selain itu media ini diharapkan juga mampu mempermudah guru dalam menyampaikan materi. Oleh karena itu penulis melakukan penelitian dengan judul "Pengembangan Media Pembelajaran Interaktif Berbasis Multimedia Pada Mata Pelajaran Informatika Kelas VII Di SMP Negeri 1 Seririt".

\section{KAJIAN TEORI}

\section{A. Multimedia Interaktif}

Multimedia interaktif merupakan sistem pengajaran dengan menggunakan teknologi yang saling berhubungan dengan pemakainya. Multimedia interaktif adalah alat yang dapat menciptakan presentasiyang dinamis dan interaktif yang mengkombinasikan teks, grafik, animasi,audio dan video. Multimedia Interaktif dalam konteks komputer adalah pemanfaatan komputer untuk membuat dan menggabungkan teks, grafik, audio, video, dengan menggunakan alat (atau program) yang memungkinkan pemakai berinteraksi, berkreasi, dan berkomunikasi secara interaktif. Menurut (Munir, 2012) menyatakan bahwa multimedia interaktif adalah suatu tampilan multimedia yang dirancang agar tampilannya memenuhi fungsi menginformasikan pesan dan memiliki interaktifitas dengan penggunanya. Pengertian ini merujuk pada kemampuan multimedia interaktif untuk berkomunikasi dengan penggunanya. Tampilannya dirancang agar pengguna dapat memperoleh informasi yang interaktif.

Berdasarkan pengertian-pengertian di atas, dapat ditarik kesimpulan bahwa multimedia interaktif adalah suatu tampilan multimedia menggunakan komputer yang mengintegrasikan beberapa macam media dimana pengguna dapat belajar secara interaktif karena dilengkapi dengan alat pengontrol yang berfungsi sebagai penghubung dengan program agar pengguna dapat memilih apa yang dikehendaki. Dalam penelitian ini keinteraktifan media didapat dari adanya pilihan menu materi yang dapat dipelajari sesuai keinginan siswa dan adanya umpan balik apabila siswa selesai mengerjakan sesuatu.

\section{B. Fungsi Multi Media Interaktif}


Dalam kegiatan pembelajaran di kelas, multimedia dapat berfungsi sebagai suplemen yang sifatnya opsional, pelengkap (komplemen), atau bahkan pengganti guru (substitusi) (Roblyer, 2006).

\section{Model-Model Multimedia Interaktif}

Darmawan menyatakan bahwa ada empat model multimedia interaktif, yaitu model drills, model tutorial, model simulasi, dan model games (Darmawan, 2012).

\section{a. Model Drills}

Model ini pada dasarnya memberikan pengalaman belajar yang lebih konkret dengan penyediaan soal-soal yang bertujuan untuk menguji penampilan siswa melalui kecepatan menyelesaikan soal-soal yang diberikan.Tahapan materi model drills yaitu sebagai berikut.

1. Program menyajian masalah dalam bentuk soal.

2. Siswa mengerjakan soal-soal latihan.

3. Program merekam penampilan siswa, mengevaluasi, dan memberikan umpan balik.

4. Apabila hasil latihan siswa sudah memenuhi kriteria, maka akan program berlanjut ke materi selanjutnya, namun jika belum akan ada fasilitas remidi yang dapat diberikan secara parsial maupun keseluruhan.

\section{b. Model Tutorial}

Model ini memberikan pengalaman belajar dengan cara memberikan materi atau informasi terlebih dahulu, kemudian siswa diberikan pertanyaan yang berhubungan dengan materi yang telah disajikan. Penyajian materi dapat dilakukan secara bertahap membentuk siklus. Tahapan pembelajaran dengan model tutorial yaitu: introduction (pengenalan); presentation of information (penyajian informasi atau materi); questions of respons (pertanyaan dan respon); judging of responses (penilaian respon); providing feedback about responses (pemberian balikan respon); remediation (pengulangan); Sequencing lesson segmen (segmen pengaturan pelajaran);

\section{c. Model Simulasi}

Model ini bertujuan memberikan memberikan pengalaman belajar yang lebih konkret melalui penciptaan tiruan-tiruan bentuk pengalaman yang mendekati suasana yang sebenarnya. Program simulasi akan mendesain bentukbentuk animasi yang detail. Ada empat kategori dalam model simulasi yaitu fisik, situasi, prosedur, dan proses. Tahapan materi dalam model simulasi yaitu:Pengenalan; penyajian informasi (simulasi 1, simulasi 2, dan seterusnya); pertanyaan dan respon jawaban; penilaian respon; pemberian feedback (umpan balik) tentang respon; pembetulan; segmen pengaturan pengajaran; penutup.

\section{d. Model Games}

\begin{abstract}
Model ini mendesain pembelajaran yang menyenangkan melalui simulasi-simulasi tertentu yang dibutuhkan agar peserta didik mampu menerapkan semua pengalaman belajarnya dalam menyelesaikan masalah yang diprogramkan. Model games bertujuan untuk menyajikan informasi dalam bentuk fakta, prinsip, proses, struktur, sistem yang dinamis, kemampuan memecahkan masalah, pengambilan keputusan, kemampuan kerja sama, kemampuan sosial, dan kemampuan insidental seperti kompetisi yang harus dialami, bagaimana kerja sama, dan aturan-aturan yang harus ditaati dalam membina disiplin siswa. Tahapan materi dalam model games yaitu sebagai berikut.
\end{abstract}

1. Introduction (pendahuluan), terdiri atas judul, tujuan, aturan, petunjuk, pilihan permainan.

2. Body of Instructional Games (bentuk instruksional permainan), terdiri atas skenario, tingkatan permainan, pelaku permainan, aturan permainan, tantangan dalam mencapai tujuan, rasa ingin tahu, kompetisi positif, hubungan bermakna antara permainan dan pembelajaran, kemampuan melawan tantangan, menang atau kalah, pilihan permainan, alur atau langkah-langkah yang harus dilakukan, pergantian tipe kegiatan, dan interaksi dalam bermain.

3. Closing (penutup) berisi pemberitahuan pemenang, pemberian reward, informasi terutama feedback untuk pemain dalam meningkatkan penampilan individual, penutup. Terdapat berbagai model multimedia interaktif yang dapat dipilih sesuai kebutuhan. Peneliti memilih model drill dan model tutorial sebagai multimedia interaktif dalam penelitian ini karena model tutorial dapat menyajikan materi berfikir komputasional dengan tampilan simpel,mudah dipahami serta dapat memberikan latihan soal sebagai evaluasi dari hasil belajar siswa. Melaui multimedia interaktif model tutorial siswa juga diharapkan dapat belajar secara mandiri dengan bantuan komputer, sehingga siswa dapat mengeksplorasi materi sesuai keinginannya.

\section{Kelebihan Multimedia Interaktif}

Multimedia interaktif merupakan media pembelajaran dengan sistem kontrol, dalam hal ini pengguna dapat menyesuaikan animasi dengan kapasitas pemrosesan informasi mereka. Berikut kelebihan menggunakan 
multimedia interaktif dalam pembelajaran (Sarwiko, 2012) diantaranya adalah sebagai berikut :

1. Sistem pembelajaran lebih inovatif dan interaktif.

2. Pengajar akan selalu dituntut untuk kreatif inovatif dalam mencariterobosan pembelajaran.

3. Mampu menggabungkan antara teks, gambar, audio, musik, animasigambar atau video dalam satu kesatuan yang saling mendukung guna tercapainya tujuan pembelajaran.

4. Menambah motivasi pembelajar selama proses belajar mengajar hingga didapatkan tujuan pembelajaran yang diinginkan.

5. Mampu menvisualisasikan materi yang selama ini sulit untuk diterangkan hanya sekedar dengan penjelasan atau alat peraga yang konvensional.

6. Melatih pembelajar lebih mandiri dalam mendapatkan ilmu pengetahuan

\section{E. Komponen Karakteristik Multimedia Interaktif}

Ariesto Hadi Sutopo dalam (Haryono, 2015) menjelaskan bahwa terdapat enam komponen dalam multimedia interaktif yaitu teks, image, animasi, audio, fullmotion dan live video, serta interactive link.

1. Teks merupakan dasar dari pengolahan kata dan informasi berbasi multimedia. Teks terbentuk dari huruf-huruf yang membentuk kata berisi suatu pesan tertentu.

2. Image atau grafik secara umum berarti still image seperti foto dan gambar yang yang sangat baik untuk menyampaikan informasi karena manusia sangat berorientasi pada visual.

3. Animasi berarti gerakan image atau video. Konsep dari animasi adalah menggambarkan sulitnya menyajikan informasi dengan satu gambar, sekumpulan gambar atau teks saja. Dengan animasi objek dapat bergerak melintasi background untuk menciptakan suatu efek yang diinginkan untuk menyampaikan informasi.

4. Audio digunakan untuk memperjelas suatu informasi dari video atau gambar. Karakteristik suatu gambar dapat dijelaskan misalnya melaui musik atau efek suara.

5. Full-motion berhubungan dengan penyimpanan sebagai video klip, sedangkan live video merupakan hasil pemrosesan yang diperoleh dari kamera.

6. Interactive link merupakan fitur yang memungkinkan pengguna untuk menyampaikan perintah tertentu kepada program. Interactive link diperlukan untuk menggabungkan elemen multimedia sehingga menjadi suatu informasi yang terpadu.

\section{F. Tujuan Pembelajaran Informatika}

Belajar Informatika bagi siswa menengah pertama itu sangat penting karena mengasah pengetahuan teknologi komputasi agar tidak gagap teknologi. Pembelajaran informatika memberikan latar belakang untuk penggunaan komputer secara profesional dalam disiplin ilmu lain. Peserta didik akan mengalami dasar yang kuat terutama dalam pemikiran komputasi melalui masalah pemecahan dengan komputer. Pengetahuan, keterampilan, dan kompetensi yang dicapai ketika mengerjakan proyek, juga dengan referensi ke kurikulum informatika. Adapun dukungan alat komputasi yang juga disediakan digunakan untuk mencapai tujuan proyek peserta didik agar lebih bersemangat untuk belajar Informatika di Sekolah.

\section{G. Materi Pembelajaran Informatika}

Materi yang akan di bahas mengenai berfikir komputasional. Konsep berfikir komputasional memeberikan cara pendekatan dan penyelesaian masalah yang baik. Keterampilan berpikir komputasional memungkinkan peserta didik untuk memecahkan masalah, merancang sistem, dan memahami perilaku manusia, dengan menggambar pada konsep ke ilmu komputer. Konsep berfikir komputasional mempunyai empat pilar pendekatan yang penting yaitu Dekomposisi, Pengenalan Pola, Abstraksi , dan Algotitme.

1. Dekomposisi dilakukan untuk memecahkan masalah kompleks menjadi lebih sederhanadan mudah di selesaikan.

2. Pengenalan pola dilakukan untuk melihat kesamaan pola dari masalah yang ada atupun masalah sebelumnya.

3. Abstraksi dilakukan untuk meghilangkan informasi yang tidak penting dan fokus pada informsi yang penting dalam penyelesaian masalah.

4. Penyusunan algoritme adalah proses membangun penyelesaian masalah dengan langkah-langkah dan aturan yang sesuai. Evaluasi dilakukan untuk memeriksa apakah algoritma yang dibangun merupakan solusi yang tepat dan terbaik.

5. Pemrograman robot merupakan contoh pendekatan permasalahan yang bersifat algoritme. Cotoh aplikasi yang dapat digunakan untuk membuat robot line follower adalah RoboMind.

6. Scratch dapaat digunakan untuk berbagai penerapan seperti membuat alur cerita, penyelesaian persoalan matematika, IPA dan berbagai penerapan yang lain. 
e-ISSN: 2685-7006 | p-ISSN: $2252-9063$

Kumpulan Artikel Mahasiswa Pendidikan Teknik Informatika

(KARMAPATI)

Volume 10, Nomor 1, Tahun 2021

\section{METODOLOGI PENELITIAN}

Penelitian ini dilakukan dengan menggunakan metode Research and Development (R \& D) atau metode penelitian dan pengembangan. Research and Development adalah metode penelitian yang digunakan untuk menghasilkan produk tertentu, dan menguji keefektifan produk tersebut (Sugiyono 2009). Penelitian ini bertujuan untuk mengembangkan sebuah media pembelajaran interaktif berbasis multimedia pada mata pelajaran Informatika kelas VII di SMPN 1 Seririt. Pengembangan media pembelajaran interaktif berbasis multimedia pada mata pelajaran Informatika kelas VII di di SMPN 1 Seririt menggunakan model MDLC (Multimedia Development Life Cycle) media pembelajaran interaktif ini dilakukan berdasarkan 6 tahap, yaitu, concept (pengonsepan), design (perancangan), material Collecting (pengumpulan bahan), assembly (pembuatan), testing (pengujian) dan distribution (pendistribusian). Menurut Binanto (2010), ke enam tahapan ini tidaklah harus berurutan dalam praktiknya, tahap-tahap tersebut dapat saling bertukar posisi, meskipun xdemikian, tahap concept memang harus menjadi hal pertama kali dikerjakan. Berikut merupakan gambar tahapan metode MDLC.

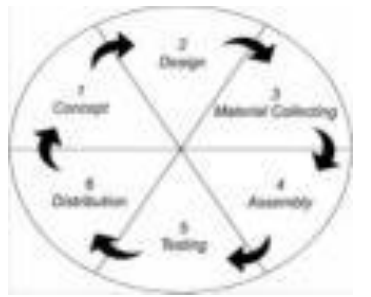

Gambar 3. 1 Metode MDLC

\section{Fase Pengonsepan (Concept)}

Tahap konsep (concept) merupakan tahap awal dari pengembangan multimedia interaktif. Kegiatan dalam tahap ini adalah penentuan ide dasar program yang akan dikembangkan yaitu dengan melakukan studi lapangan dan mengumpulkan referensi mengenai pokok bahasan yang diambil.

\section{Fase Perancangan (Design)}

Pada tahap ini membuat spesifikasi secara rinci mengenai arsitektur proyek, gaya, tampilan dan kebutuhan material/bahan untuk program. Spesifikasi dibuat cukup rinci, sehingga pada tahap berikutnya, yaitu material collecting dan assembly. Tahap ini biasanya menggunakan storyboard untuk menggambarkan deskripsi tiap scane, dengan mencantumkan semua objek media pembelajaran dan tautan dari scene ke scene lain. Pada tahap ini, untuk menggambarkan perancangan dari tiap tiap scene, untuk tahap ini perlu dibuat perancangan skenario.

Skenario, merupakan sebuah naskah cerita yang menguraikan urutan-urutan adegan, tempat, keadaan, dan dialog, yang disusun dalam konteks struktur dramatik untuk menjadi acuan dalam proses produksi, yang pada media ini skenario media pembelajaran interaktif dari awal sampai akhir.

\section{Fase Pengumpulan Bahan (Material Collecting)}

Material Collecting adalah tahap pengumpulan bahan yang sesuai dengan kebutuhan. Bahan-bahan tersebut antara lain gambar, foto, animasi, video, audio, serta teks baik yang sudah jadi, ataupun yang masih perlu dimodifikasi sesuai dengan kebutuhan yang ada. Bahan-bahan tersebut dapat diperoleh secara gratis 4 atau dengan pemesanan kepada pihak lain sesuai dengan rancangan yang telah dibuat pada tahap sebelumnya. Pada tahap pengumpulan bahan, bahan yang dikumpulkan adalah berupa teks, gambar, animasi, suara dan mengumpulkan bahan-bahan materi dan soalsoal yang akan ditampilkan dalam media pembelajaran. Bahan bahan yang digunakan untuk kebutuhan aplikasi diperoleh dari membuat sendiri dengan menggunakan Articulate Storyline 3 atau aplikasi pendukung lainnya.

\section{Fase Pembuatan (Asembly)}

Tahap assembly adalah tahap pembuatan keseluruhan bahan multimedia. Aplikasi yang akan dibuat didasarkan pada tahap design, seperti storyboard dan mengacupada sinopsis yang telah dibuat. Tahap ini biasanya menggunakan perangkat lunak Articulate Storyline 3 . Tahap Asembly merupakan bagian dari kegiatan produksi animasi, penyusunan teks, dan lain-lain. Pada tahap ini, media pembelajaran mulai dikembangkan sesuai dengan yang sudah ditetapkan pada tahap design. Pembuatan atau proses produksi media pembelajaran interaktif, membutuhkan alur kerja produksi yang teratur dan sistematis agar waktu produksi bisa berjalan lebih efektif dan juga tepat sasaran, sesuai dengan target waktu yang direncanakan. Yang akan dilakukan pada tahap Asembly ini adalah produksi dan pasca poduksi. Berikut merupakan tahapan dari kedua proses pembuatan. Produksi, Pada tahap produksi media pembelajaran dibuat sesuai kebutuhan dari pra produksi yang telah dirancang.Pasca produksi, Pengkomposisian dan editing dalam pembuatan sebuah media pembelajaran adalah hal yang sangat utama. Karena pada tahap inilah adenganadegan yang sudah dirender kemudian disatukan, dirangkai dan diberi suara. Produk media pembelajaran yang dihasilkan nantinya berupa DVD dan akan diberikan ke sekolah yang bersangkutan sebagai bahan ajar. Pada Tahap 
ini juga, merupakan tahap pembuatan seluruh objek berdasarkan perancangan yang telah dibuat sebelumnya. Pada praktiknya, tahap ini bisa dilakukan dengan tahap pengumpulan bahan, karena disesuaikan dengan kebutuhan.

\section{Fase Pengujian (Testing)}

Pada tahap ini akan dilaukan pengujian pada aplikasi yang dibuat. Tahap pengujian dilakukan tidak setelah aplikasi jadi seluruhnya,tetapi dilakukan per scene atau dilakukan ditengah tengah proses pembuatan. Aplikasi harus berjalan dengan baik pada perangkat komputer manapun. Apabila ada kesalahan, aplikasi akan dibetulkan, jika sudah berjalan sesuai dengan rancangan dan tujuan, proses akan masuk ke tahap selanjutnya yaitu penyelesaian dan distribusi. Pada tahap testing, terdapat uji ahli isi materi, uji ahli media, uji respon siswa dan uji efektifitas. Pengujian dilakukan untuk memastikan bahwa hasil pembuatan aplikasi multimedia sesuai dengan rencana. Ada dua jenis pengujian yang digunakan, yaitu pengujian alpha dan pengujian beta. Pengujian alpha seperti menampilkan tiap halaman, fungsi tombol serta suara yang dihasilkan. Jika ada malfunction maka aplikasi akan segera diperbaiki. Jika telah lolos dalam pengujian alpha maka akan dilanjutkan dengan pengujian beta. Pengujian beta adalah pengujian yangdilakukan oleh pengguna, dengan membuat kuisioner tentang aplikasi yang dibuat.

\section{Distribution (Pendistribusian)}

Distribution adalah tahap aplikasi selesai dibuat, aplikasi diexport menjadi file *.exe, agar aplikasi tersebut dapat dijalankan dengan mudah di perangkat computer dan disimpan dalam suatu media penyimpanan seperti Flashdisk, dan CD yang sebelumnya sudah dijadikan file autoplay. Tahap pendistribusian termasuk dalam tahap evaluasi karena adanya evaluasi sangat dibutuhkan untuk mengembangkan produk yang sudah dibuat sebelumnya agar mejadi lebih baik. Tahap ini merupakan tahap akhir dimana media telah siap didistribusikan di sekolah

\section{HASIL DAN PEMBAHASAN}

\section{A. HASIL}

Hasil penelitian terkait pengembangan "Pengembangan Media Pembelajaran Interaktif Berbasis Multimedia Pada Mata Pelajaran Informatika Kelas VII Di SMP Negeri 1 Seririt" dengan menggunakan model MDLC (Multimedia Development Life Cycle) yang terdiri dari 6 tahapan diantaranya adalah concept (konsep), design (desain), material collecting (pengumpulan bahan), assembly (pembuatan), testing (pengujian), dan distribution (pendistribusian). Berikut ini merupakan hasil terkait uraian menggunakan metode MDLC.

\section{Hasil Fase Pengonsepan (Concept)}

Pada penelitian tahap Konsep, beberapa hasil terkait pengembangan konsep yang telah dirancang, seperti konsep media pembelajaran secara umum. Berikut merupakan penjelasan rinci terkait hasil ditahap konsep media pembelajaran ini, diantaranya adalah sebagai berikut :

Tabel 4. 1 Spesifikasi media pembelajaran.

\begin{tabular}{|c|c|c|}
\hline No. & Konsep & Keterangan \\
\hline 1. & Judul & $\begin{array}{l}\text { Pengembangan } \\
\text { Pembelajaran Interaktif Berbasis } \\
\text { Multimedia Pda Mata Pelajaran } \\
\text { Informatika Kelas VII Di SMP } \\
\text { Negeri 1 Seririt }\end{array}$ \\
\hline 2. & Pengguna & $\begin{array}{l}\text { Pengguna media pembelajaran ini } \\
\text { diperuntukan untuk guru yang } \\
\text { mengampu mata pelajaran } \\
\text { informatika dan siswa kelas VII } \\
\text { SMP Negeri } 1 \text { Seririt }\end{array}$ \\
\hline 3. & Tujuan & $\begin{array}{l}\text { Tujuan pembuatan media } \\
\text { pembelajaran multimedia } \\
\text { interaktif ini adalah membantu } \\
\text { menciptakan proses pembelajaran } \\
\text { yang berbeda dari sebelumnya. } \\
\text { Media pembelajaran ini } \\
\text { diharapkan mampu meningkatkan } \\
\text { motivasi guru dalam melakukan } \\
\text { proses pembelajaran } \\
\text { begitu juga untuk siswa dengan } \\
\text { media pembelajaran ini } \\
\text { diharapkan siswa memiliki } \\
\text { motivasi yang tinggi untuk } \\
\text { belajar. }\end{array}$ \\
\hline 4. & Jenis Media & $\begin{array}{l}\text { Jenis media interaktif yang dibuat } \\
\text { adalah berupa video pembelajaran }\end{array}$ \\
\hline 5. & Pedoman Materi & $\begin{array}{l}\text { Isi materi pembelajaran mengacu } \\
\text { pada sumber buku yang diberikan } \\
\text { oleh guru sekolah menengah } \\
\text { pertama } \quad \text { dengan }\end{array}$ \\
\hline
\end{tabular}




\begin{tabular}{|c|c|c|}
\hline & & $\begin{array}{l}\text { “ Informatika untuk SMP/MTs } \\
\text { Kelas VII" Kurikulum } 2013 \text { revisi } \\
\text { oleh Henry Pandia, S.T.,M.T. }\end{array}$ \\
\hline 6. & $\begin{array}{l}\text { Konsep Isi } \\
\text { Materi }\end{array}$ & $\begin{array}{l}\text { Mengenal dan Menerapkan } \\
\text { Konsep Berpikir Komputasional }\end{array}$ \\
\hline 7. & Gambar & $\begin{array}{l}\text { Gambar yang digunakan file } \\
\text { berformat .png dan .jpg }\end{array}$ \\
\hline 8. & Cara Pembuatan & $\begin{array}{l}\text { Pembuatan media pembelajaran } \\
\text { ini menggunakan } \\
\text { Articulate Storyline } 3 \text { sebagai } \\
\text { proses dasar } \\
\text { pembuatan media ini. Tahap } \\
\text { pertama, dalam } \\
\text { pembuatan. kemudian di publish } \\
\begin{array}{l}\text { palam bentuk WEB html 5 } \\
\text { atau .exe, }\end{array}\end{array}$ \\
\hline 9. & Audio & $\begin{array}{l}\text { Menggunakan file yang } \\
\text { berformat .mp3 dan .wav yang } \\
\text { diambil dari berbagai sumber } \\
\text { serta hasil rekaman peneliti. }\end{array}$ \\
\hline 10. & Video & $\begin{array}{l}\text { Video materi pada media tersebut } \\
\text { menggunakan } \\
\text { Menggunakan Animaker, } \\
\text { berformat.MP4 }\end{array}$ \\
\hline 11. & Output & $\begin{array}{l}\text { Hasil akhir pengembangan media } \\
\text { pembelajaran ini berupa kepingan } \\
\text { CD/DVD yang akan diberikan ke } \\
\text { pihak sekolah tempat penelitian. }\end{array}$ \\
\hline 12. & Interaktivitas & $\begin{array}{l}\text { Tombol menu-menu dan submenu } \\
\text { untuk menuju ke KI/KD, materi, } \\
\text { video pembelajaean, kuis, } \\
\text { maupun yang lainnya, tombol- } \\
\text { tombol untuk perpindahan dari } \\
\text { satu scene ke scene lain. Tombol } \\
\text { panah untuk menuju ke halaman } \\
\text { selanjutnya, tombol kembali ke } \\
\text { beranda untuk kembali ke } \\
\text { halaman sebelumnya. Tombol } \\
\text { keluar untuk keluar program, dan } \\
\text { tombol volume untuk } \\
\text { menghidupkan dan mematikan } \\
\text { volume backsound }\end{array}$ \\
\hline
\end{tabular}

\section{Hasil Fase Perancangan (Design)}

Pada tahap ini membuat spesifikasi secara rinci mengenai arsitektur proyek, gaya, tampilan dan kebutuhan material/bahan untuk program. Spesifikasi dibuat cukup rinci, sehingga pada tahap berikutnya, yaitu material collecting dan assembly. Tahap ini biasanya menggunakan storyboard untuk menggambarkan deskripsi tiap scane, dengan mencantumkan semua objek media pembelajaran dan tautan dari scene ke scene lain. Pada tahap ini, untuk menggambarkan perancangan dari tiap tiap scene.

\section{Hasil Fase Pengumpulan Bahan (Material Collecting)}

Material Collecting adalah tahap pengumpulan bahan yang sesuai dengan kebutuhan. Bahan-bahan tersebut antara lain gambar, foto, animasi, video, audio, serta teks baik yang sudah jadi, ataupun yang masih perlu dimodifikasi sesuai dengan kebutuhan yang ada. Bahan-bahan tersebut dapat diperoleh secara gratis atau dengan pemesanan kepada pihak lain sesuai dengan rancangan yang telah dibuat pada tahap sebelumnya. Pada tahap pengumpulan bahan, bahan yang dikumpulkan adalah berupa teks, gambar, animasi, suara dan mengumpulkan bahan-bahan materi dan soal-soal yang akan ditampilkan dalam media pembelajaran. Bahan bahan yang digunakan untuk kebutuhan media pembelajaran diperoleh dari membuat sendiri dengan menggunakan buku yang ada disekolah sebagai materi, Articulate Storyline 3, serta beberapa bahan yang diambil dari internet yang kemudian diolah dengan sotware yang telah disebutkan sebelumnya.

\section{Hasil Fase Pembuatan (Asembly)}

Tahap assembly adalah tahap pembuatan keseluruhan bahan multimedia. Aplikasi yang akan dibuat didasarkan pada tahap design, seperti storyboard dan mengacu pada sinopsis yang telah dibuat. Tahap ini biasanya menggunakan perangkat lunak Articulate Storyline 3. Tahap Asembly merupakan bagian dari kegiatan produksi animasi, penyusunan teks, dan lain-lain. Pada tahap ini, media pembelajaran mulai dikembangkan sesuai dengan yang sudah ditetapkan pada tahap design. Pembuatan atau proses produksi media pembelajaran interaktif, membutuhkan alur kerja produksi yang teratur dan sistematis agar waktu produksi bisa berjalan lebih efektif dan juga tepat sasaran, sesuai dengan target waktu yang direncanakan. Yang akan dilakukan pada tahap Asembly ini adalah produksi dan pasca poduksi. Berikut merupakan tahapan dari kedua proses pembuatan.

\begin{tabular}{|c|c|}
\hline $\begin{array}{c}\text { Perancangan } \\
\text { Storyboard }\end{array}$ & $\begin{array}{c}\text { Implementasi } \\
\text { Storyboard }\end{array}$ \\
\hline
\end{tabular}


e-1SSN: 2685-7006|p-ISSN: 2252-9063

Kumpulan Artikel Mahasiswa Pendidikan Teknik Informatika

(KARMAPATI)

Volume 10, Nomor 1, Tahun 2021

KคRMดPคTI

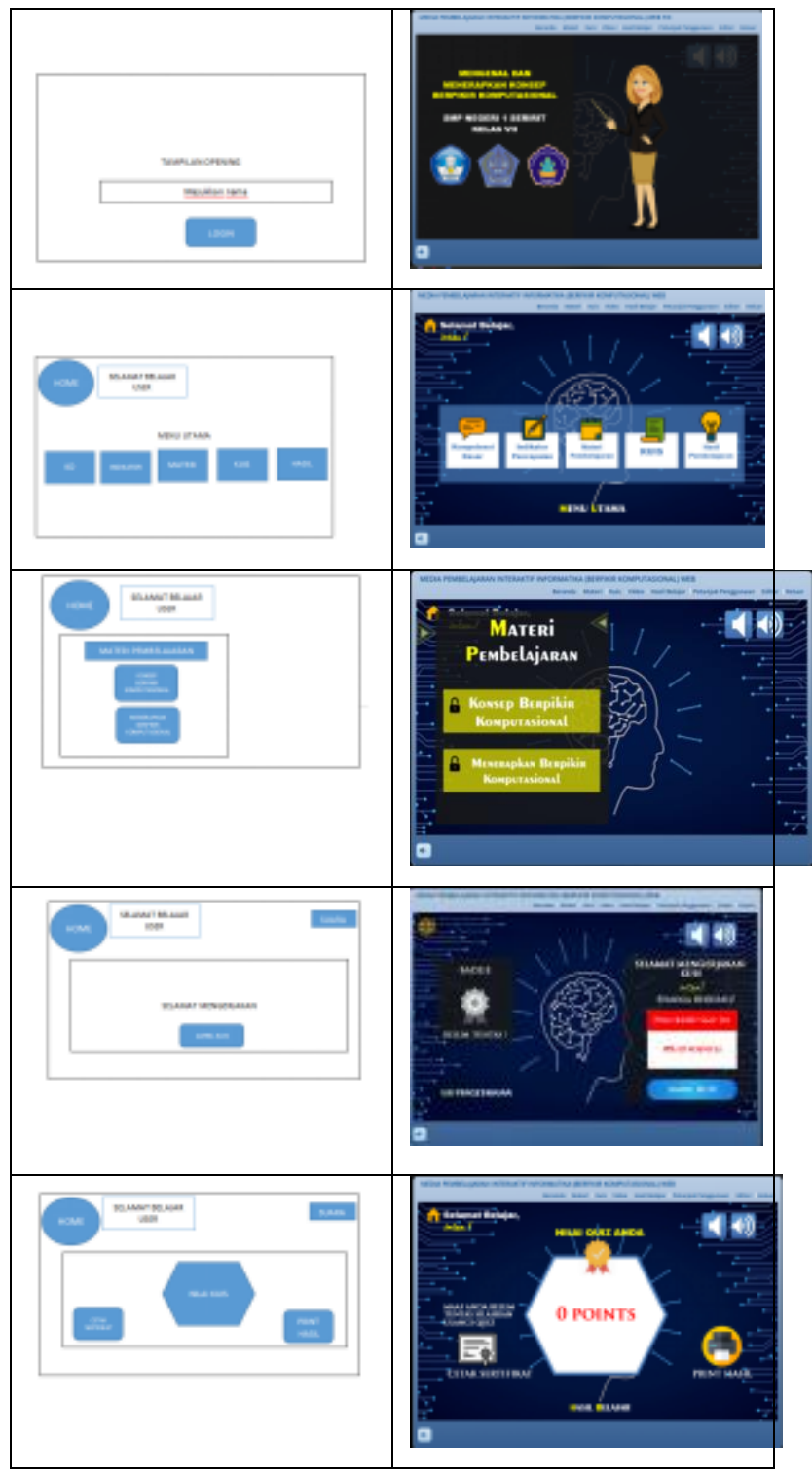

\section{Hasil Tahap Pengujian}

Tahap pengujian ini dilakukan sebelum film animasinya selesai keseluruhan artinya dilihat per adegan. Setiap adegan harus sudah berjalan dengan baik pada perangkat computer manapun, jika ada kesalahan maka akan dilakukan revisi sesuai arahan dari pembimbing.

\section{A. Uji Ahli Isi}

Uji ahli isi dilakukan oleh 2 orang dengan membandingkan kedua jawaban tersebut.

$$
\text { Validasi isi }=\frac{D}{A+B+C+D}=\frac{5}{5}=1.00
$$

\section{B. Uji Ahli Media}

Tidak jauh berbeda dengan uji ahli isi, uji ahli mediapun sama dengan membandingkan kedua jawaban tersebut.

$$
\text { Validasi meda dan desain }=\frac{D}{A+B+C+0}=\frac{6}{6}=1.00
$$

\section{Fase Pendistribusian( Distribution)}

Pada tahap ini media pembelajaran yang selesai dibuat akan ditaruh dalam wujud file*. exe serta dimasukkan kedalam CD( Compact Disk). Sesudah itu CD yang telah jadi diberikan ke sekolah penelitian terkait untuk digunakan sebagaimana mestinya.

\section{B. PEMBAHASAN}

Berdasarkan paparan hasil penelitian, maka berikut ini akan diuraikan pembahasan. Pembahasan berfokus pada analisis data serta revisi yang dilakukan pengembangan produk. Tahap konsep (consept) meliputi kegiatan sebagai berikut: a) menentukan tujuan pembelajaran, b) konsep materi pembelajaran, c) konsep isi media pembelajaran. Tahap kedua adalah perancangan (design) melakukan peracangan materi dan storyboard.

Tahap ketiga adalah pengumpulan bahan materi (material collecting) yang meliputi pengumpulan bahan teks, bahan gambar, bahan animasi, dan bahan audio. Tahap keempat adalah pembuatan (assembly) proses pembuatan media pembelajaran sesuai dengan storyboard yang telah dibuat sebelumnya. Tahap selanjutnya adalah pengujian (testing) menjalankan media pembelajaran dan melihat apakah ada kesalahan atau tidak dalam media pembelajaran yang dikembangkan. Setelah melakukan pengujian media pembelajaran di distribusikan ke sekolah untuk dijadikan sebagai penunjang pembelajaran.

Dalam proses pengembangan media dari tahap konsep sampai pengujian peneliti melakukan koordinasi dengan guru pembimbing untuk menghasilkan media pembelajaran sesuai dengan kebutuhan. Peneliti melakukan bimbingan dari segi isi materi, gambar penunjang materi, penggunaan animasi, penggunaan teks, penggunaan warna, ukuran setiap gambar penunjang materi. Sehingga hasil pengembangan media menyesuaikan dengan hasil bimbingandengan guru bidang studi informatika. Media pembelajaran kemudian di uji coba melalui beberapa tahapan uji coba dimulai dari 
e-ISSN: 2685-7006 | p-ISSN: $2252-9063$

Kumpulan Artikel Mahasiswa Pendidikan Teknik Informatika

(KARMAPATI)

Volume 10, Nomor 1, Tahun 2021

review para ahl. Uji ahli yang pertama dilakukan adalah uji ahli isi pembelajaran. Setelah melakukan uji ahli isi, kemudian dilanjutkan dengan uji ahli media pembelajaran.

Hasil pengujian ahli isi dengan menggunakan uji Gregory berdasarkan angket menunjukkan bahwa tingkat pencapaian dari media pembelajaran interaktif berbasis multimedia adalah "Sangat Tinggi" dan layak untuk dilanjutkan, namun ada beberapa saran perbaikan dari ahli isi untuk melakukan perbaikan. Setelah itu dilakukan revisi oleh penulis untuk menyempurnakan media pembelajaran interaktif berbasis multimedia. Hal tersebut mengindikasikan bahwa materi pelajaran yang diimplementasikan dalam media sudah relevan untuk digunakan dalam pembelajaran informatika. Materi pelajaran disesuikan dengan silabus kemudian divisualisasikan melalui video dan animasi sehingga memudahkan pemahaman materi oleh siswa. Hasil pengujian ahli media pembelajaran berdasarkan angket menunjukkan bahwa tingkat pencapaiannya adalah "Sangat Tinggi", namun ada beberapa saran perbaikan dari penguji untuk melakukan perbaikan. Setelah itu dilakukan revisi oleh penulis untuk menyempurnakan media pembelajaran interaktif berbasis multimedia.

Berdasarkan hasil uji ahli dan yang dilakukan serta penuturan dari guru bidang studi informatika media pembelajaran interaktif yang dikembangan efektif digunakan dalam pembelajaran informatika.

\section{SIMPULAN}

Kesimpulan yang dapat diperoleh dari penelitian Pengembangan Media Pembelajaran Interaktif Berbasis Multimedia Pada Mata Pelajaran Informatika Kelas VII Di SMP Negeri 1 Seririt adalah :

1. Hasil rancangan dan implementasi Pengembangan Media Pembelajaran Interaktif Berbasis Multimedia Pada Mata Pelajaran Informatika Kelas VII Di SMP Negeri 1 Seririt menggunakan metode pengembangan MDLC dengan enam tahapan yaitu Concept, Design, Material collecting, Assembly, Testing, dan Distribution. Pengujian (testing) dilakukan melalui alpa testing. Alpa testing terdiri dari uji ahli isi dan uji ahli media untuk mengetahui kevalidan media pembelajaran serta serta isi dari media pembelajaran apakah sudah sesuai dengan sehingga media dapat diterapkan.

2. Pengembangan Media Pembelajaran Interaktif Berbasis Multimedia Pada Mata Pelajaran Informatika Kelas VII Di SMP Negeri 1 Seririt mampu menjadi sumber belajar bagi siswa. Media pembelajaran digunakan sebagi panduan belajar siswa, sehingga dapat meningkatkan konsentrasi dan fokus pada siswa serta membantu proses belajar siswa di sekolah.

\section{REFERENSI}

[1] Artawan, Putu. dan Iwan Suswandi. 2014. "Pengembangan Media Pembelajaran Interaktif Dengan Macromedia Flash Untuk Meningkatkan Prestasi Fisika Siswa SMPN 1 Seririt"

[2] Candiasa, I. M. 2010. Pengujian Instrumen Penelitan Disertai ITEMAN dan BIGSTEP. Singaraja: Universitas Pendidikan Ganesha.

[3] Fatimah, Dini Destiani Siti. Dewi Tresnawati, dan Agus Nugraha 2019. "Media Pembelajaran Pengenalan Komponen Komputer Berbasis Multimedia Dengan Pendekatan Metodologi (R\&D)".

[4] Mustika, Adhy Sugara,Eka Prasetya dan Maissy Pratiwi. 2017. 'Pengembangan Media Pembelajaran Interaktif Dengan Menggunakan Metode Multimedia Development Life Cycle".

[5] Kustandi, Cecep. Bambang Sutjipto. 2013. Media Pembelajaran. Jakarta: Ghalia Indonesia.

[6] Pandia, Henry. 2019. Informatika Untuk SMP/MTs Kelas VII. Jakarta: Erlangga.

[7] Pendiartawan, Kadek. Dkk. 2016. "Pengembangan Multimedia Pembelajaran Interaktif Dengan Model ADDIE Pada Mata Pelajaran IPA Kelas VIII DI SMPN 1 Seririt"

[8] Sugiyono. 2009. Motode Penlitian Kuantitatif, Kualitatif, Dan R\&D. CV.Alfabeta.

[9] Usfiyana, Ifa. (2019). "Pengembangan Media Pembelajaran Berbasis Adobe Flash CS6 Untuk Mata Pelajaran Teknologi Informasi Dan Komunikasi TIK) di smp al-ishlah semarang".

[10] Wahyu Pramudita, Sugeng Wahyudiono, dan Kapti .2019. "Media Pembelajaran Multimedia Interaktif Tentang Pengelolaan Sampah Pada SDN Sidoagung 2".

[11] Wulandari, Berlina. Fiqri Ardiansyah, Puspa Eosina,dan Hersanto Fajri. 2019. "Media Pembelajaran Interaktif IPA untuk Sekolah Dasar Berbasis Multimedia". Diakses 31 januari 2020.

[12] Darmawan,Putu Arya Yoga (2019). Pengembangan Media Pembelajaran Multimedia Interaktif "Elementary Communicative English For Beginners" Mata Pelajaran Bahasa Inggris Kelas IV Di Sekolah Dasar. Universitas Pendidikan Ganesha. 